\title{
A Tribute to Leonardo N. Mercado, SVD: His Legacy to the Filipino Nation
}

\section{Emmanuel D. Batoon}

\begin{abstract}
This essay highlights Leonardo N. Mercado's legacy to the Filipino nation by reading his text, Elements of Filipino Philosophy, through the lens of critical theory. The article begins with a description of critical theory as a methodological framework in reading a text, followed by a discussion of Mercado's political interest behind his text. The essay ends by examining the relevance of his text's meaning in addressing a social crisis like the COVID-19 pandemic.
\end{abstract}

Keywords: Mercado, Filipino philosophy, Filipino nation, COVID-19

\section{Introduction}

7 his essay highlights the legacy of Rev. Fr. Leonardo N. Mercado, SVD, Ph.D. to the Filipino nation by reading his text, Elements of Filipino Philosophy, ${ }^{1}$ using the lens of critical theory as a methodological framework. ${ }^{2}$ Critical theory is an interpretive framework that presumes that a text, such as Mercado's, does not just carry meaning but also an interest in power. Thus, to learn the interest in power and meaning of a text, the text must be situated within its historical context, where the question asked is, "Against whom and for whom is the text?"

\section{Against Whom is Mercado's Text?}

Mercado's text was against the forces vying for power and dominance during the 1970s: on the right were the oligarchs who wanted to maintain an elitist democracy; on the left were the communists who wanted to change Philippine society through a bloody revolution conveyed in Jose Maria Sison's (under the pseudonym Amado Guerrero) book, Philippine

${ }^{1}$ Leonardo N. Mercado, Elements of Filipino Philosophy (Tacloban City: Divine Word University Publications, Inc., 1973).

${ }^{2}$ Emmanuel D. Batoon, A Guide to Thesis Writing in Philosophy - Part One: Proposal Writing (Manila: REJN Publishing, 2005), 62.

(c) 2020 Emmanuel D. Batoon

https://www.kritike.org/journal/issue 27/batoon december2020.pdf

ISSN 1908-7330 


\section{MERCADO'S LEGACY TO THE FILIPINO NATION}

Society and Revolution; ${ }^{3}$ at the periphery was the Moro National Liberation Front (MNLF) headed by Nur Misuari, who wanted to establish the Bangsamoro as an independent nation from the Filipino nation; and at the center was Ferdinand E. Marcos's government who claimed to effect a revolution from the center to build a new society through the use of Martial Law. ${ }^{4}$

Through his missionary assignments in the Philippines as an SVD (Societas Verbi Divini or Society of the Divine Word), Mercado encountered ethnic groups and cultures distinct from his own Visayan-Cebuano culture. Through these encounters, he noticed that people carried prejudices against other groups of people. For example, some Luzon people were biased against Visayan people, as shown in their use of Visayan people as scapegoats for whatever was wrong with their social life. Ultimately, his text was at odds with those against Filipinos for being Filipinos and who believe that "to be is to be the colonizer." 5

Mercado's text resisted, as well, those who did not entertain the possibility of a philosophical alternative to the existing philosophies taught in academe during his time-Scholasticism/Thomism and existentialism. The text also opposed those who maintained academic disciplinal rigidities and territorial limits in terms of research methods.

Finally, Mercado's text opposed those who claimed that Filipino philosophy does not exist because it is not written. The text was also opposed to those who think that Filipinos do not have a sense of society because they create factions like kami-kami and kayo-kayo; that Filipinos are emotional and cannot engage in logical thinking; that they are less human than other cultures because they do not emphasize their rationality; that Filipinos do not have a moral sense; that their relationship with nature is that of domination and control; and that Filipino Catholicism is not in conformity with Orthodoxy and was not Roman enough.

\section{For Whom is Mercado's Text?}

Mercado's use of the 1973 Constitution's definition of the Filipino ${ }^{6}$ showed that his text was meant for Filipinos in general. In particular, he dedicated his work to the Filipino masses, as expressed in his preface to the Elements of Filipino Philosophy. ${ }^{7}$ Thus, his text was for the oligarchs as Filipinos,

\footnotetext{
${ }^{3}$ Amado Guerrero, Philippine Society and Revolution (Hong Kong: Ta Kung Pao, 1971).

${ }^{4}$ Ferdinand E. Marcos, Revolution from the Center: How the Philippines is Using Marital Law to Build a New Society (Hong Kong: Raya, 1978).

${ }^{5}$ Paulo Freire, Pedagogy of the Oppressed (New York: Seabury Press, 1970).

${ }^{6}$ Mercado, Elements of Filipino Philosophy, 5.

${ }^{7}$ Mercado, Preface to Elements of Filipino Philosophy, xi.
} 
excluding their marginalization of the Filipino masses. Mercado's text also welcomed the communists concerned with the Filipino masses, but never their advocacy of a bloody revolution. His text recognized the MNLF's fight for their autonomy, but not the letting go of their inclusion in the Filipino nation. Mercado's text was also a reinforcement of Ferdinand Marcos's move to establish a new society without using Martial Law as means. Thus, Mercado's text was an invitation to all political forces to focus on their being Filipinos as the common ground in building a new society.

His text was for those who see many similarities among the different Philippine ethnic groups, which can form a Filipino philosophy. The text showed this by identifying the commonalities among the Visayan, Tagalog, and Ilocano languages and behaviors. Additionally, the text indicated that the Visayans were not at all different from the rest of the Philippine ethnic groups. Ultimately, the Elements of Filipino Philosophy showed no other way for Filipinos "to be," but "to be" Filipinos.

Mercado's text favored those looking for an alternative philosophy to the formal academic philosophies of Scholasticism/Thomism and existentialism: Filipino cultural philosophy. ${ }^{8}$ And the text justified the use of social science methods ${ }^{9}$ as the appropriate method to recover the Filipino people's philosophy.

And what did the contents of the text favor?

The text favored the idea that Filipino philosophy exists. The text showed that Filipinos have a sense of society, the sakop, which they understand as a community of persons; the Filipinos' mind focuses on intuitive thinking because it provides them with an insight into the self or loob of an individual, which is the condition of possibility for their interpersonal relations; Filipinos have morality with mercy (awa) and concern (malasakit) as norms; and Filipinos extend their interpersonal relationship to nature and living in harmony with nature. Finally, Filipinos have acculturated or inculturated ${ }^{10}$ Catholicism to make it their own, and Fr. Mercado elaborated this concept in his subsequent publications on Filipino theology ${ }^{11}$ and Filipino religious psychology. ${ }^{12}$

${ }^{8}$ Emmanuel Batoon, “Tracing Mercado's Anthropological Perspective on Filipino Philosophy," in Kritike: An Online Journal of Philosophy, 8:1 (2014), 3.

${ }^{9}$ Leonardo N. Mercado, Research Methods in the Philippine Context (Tacloban City: Divine Word University Publications, Inc., 1983).

${ }^{10}$ Leonardo N. Mercado, Inculturation and Filipino Theology (Tacloban City: Divine Word Publications, Inc., 192).

${ }^{11}$ Leonardo N. Mercado, Elements of Filipino Theology (Tacloban City: Divine Word University Publications, Inc., 1975).

${ }_{12}$ Leonardo N. Mercado, Filipino Religious Psychology (Tacloban City: Divine Word University Publications, Inc., 1977).

(c) 2020 Emmanuel D. Batoon

https://www.kritike.org/journal/issue 27/batoon december2020.pdf

ISSN 1908-7330 
But are the Elements still relevant in explaining Filipinos' behavior during the COVID-19 pandemic?

\section{The Relevance of Mercado's Elements of Filipino Philosophy in Explaining Filipinos' Behavior under the COVID-19 Pandemic}

I recently attended a web-conference lecture, titled Political Collectivism under COVID-19, by Marc Wenyi Lai, a Taiwanese political scientist. ${ }^{13}$ Lai started his lecture by showing the following statistics on COVID-19 cases and deaths worldwide as of 5 December 2020: the US had $13,000,000$ cases and 200,000 deaths; India had 9,000,000 cases and 138,000 cases; Brazil had 6,000,000 cases and 173,000 deaths; Russia had 2,500,000 cases and 41,600 deaths; France had 2,000,000 and 53,000 deaths; and Spain had 1,500,000 cases and 47,000 deaths. In contrast, China had 93,797 cases and 4,000 deaths, and Taiwan had 6,861 and 81 deaths.

Eventually, Lai explained that China and Taiwan's figures were relatively low compared to the other countries because the Chinese mainlanders and the Taiwanese have a Confucian culture of obedience. This culture extends to other nations like Singapore, Vietnam, Korea, and Japanall of which showed low COVID-19 cases and deaths. The ultimate result is that these nations possess a sense of political collectivism.

If we compare the Philippine statistics on COVID-19 cases and deaths on the same date, there were 44,000 cases and 8,572 deaths. The figures show that the Philippines is relatively nearer to China and Taiwan's figures than the US and the other nations mentioned earlier with high figures on cases and deaths. How can the statistics be explained?

Filipino philosophy can explain the Philippine statistics. The pandemic awakened the Filipinos' sense of society as sakop, which the authorities supported through the use of the slogans, "Pilipino kami; COVID ka lang," and "Together, we heal as one." Filipinos' intuitive thinking was reinforced, urging them to look into their fellow Filipinos' (kababayan) interiority (kalooban) and show mercy (awa) and concern (malasakit) for one another. The Filpino health workers abroad whom the British and Americans acclaimed for their care and sacrifices exemplified this moral practice. The pandemic also made Filipinos acknowledge nature's power over them and reminded them to respect and live in harmony with nature, not dominate and control nature. Finally, their sense of the sacred gave them refuge in this time of crisis.

${ }^{13}$ Marc Wenyi Lai, "Political Collectivism under COVID-19" (lecture presented at a web-conference organized by The Graduate School of the University of Santo Tomas, 5 December 2020).

(C) 2020 Emmanuel D. Batoon

https://www.kritike.org/journal/issue 27/batoon december2020.pdf

ISSN 1908-7330

(c) $)$ BY-NC-ND 
Now that its political interest and meaning had been exposed, and its relevance in explaining the behavior of Filipinos during the COVID-19 pandemic, Mercado's Elements of Filipino Philosophy can be considered as a continuation of his fellow Filipino Thomasians' attempt to imagine the nation: starting from Jose Rizal, who first conceived of the Filipino nation through his novels Noli Me Tangere (Touch Me Not, 1887) and El Filibusterismo (Filibusterism, 1891), to Apolinario Mabini's "Programa constitucional de la República Filipina" ("The Constitutional Program of the Philippine Republic," 1898), down to Manuel L. Quezon who encouraged Filipinos to resist the Japanese invaders through his speech, "A Message to My People." Ultimately, Mercado's Elements of Filipino Philosophy stands as a testament to a life well-lived.

Department of Political Science, University of Santo Tomas, Philippines

\section{References}

Batoon, Emmanuel D., A Guide to Thesis Writing in Philosophy - Part One: Proposal Writing (Manila: REJN Publishing, 2005).

“Tracing Mercado's Elements of Filipino Philosophy (First of Two Parts)," in Kritike, 8:1 (2014).

De Leon, Emmanuel and Marvin Einstein Mejaro, "An Interview with Leonardo Nieva Mercado, SVD," in Kritike, 10:2 (2016).

Freire, Paulo, Pedagogy of the Oppressed (New York: Seabury Press, 1970).

Guerrero, Amado, Philippine Society and Revolution (Hong Kong: Ta Kung Pao, 1971).

Lai, Marc Wenyi, "Political Collectivism under COVID-19" (lecture presented at a web-conference organized by The Graduate School of the University of Santo Tomas, 5 December 2020).

Marcos, Ferdinand E., Revolution from the Center: How the Philippines Uses Martial Law to Build a New Society (Hoong Kong: Rya, 1978).

Mercado, Leonardo N., Elements of Filipino Philosophy (Tacloban City: Divine Word University Publications, Inc., 1973).

Elements of Filipino Theology (Tacloban City: Divine World University Publications, Inc., 1975). Filipino Religious Psychology (Tacloban City: Divine Word

University Publications, Inc., 1977). Research Methods in the Philippine Context (Tacloban City: Divine Word University Publications, Inc., 1983). Inculturation and Filipino Theology (Manila: Divine Word University Publications, Inc., 1992).

(c) 2020 Emmanuel D. Batoon

https://www.kritike.org/journal/issue 27/batoon december2020.pdf

ISSN 1908-7330 